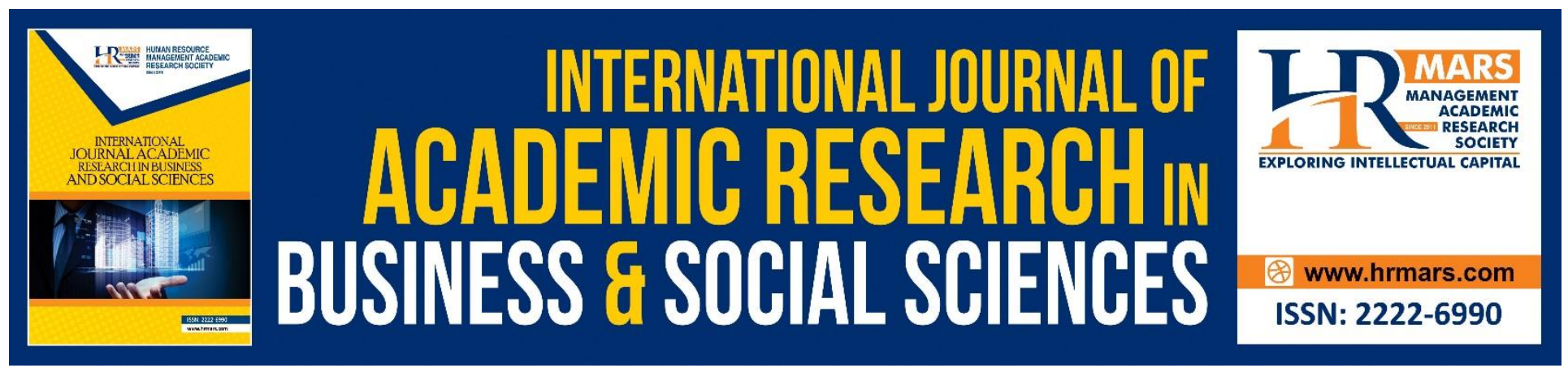

\title{
The Critical Factors towards the Charismatic Leadership Effectiveness in National Defense University of Malaysia
}

\section{Hj. Hasan Al-Banna Mohamed, Mohd Hamran Mohamad, Mohd Kamarul Amree Mohd Sarkam}

To Link this Article: http://dx.doi.org/10.6007/IJARBSS/v9-i1/5865

DOI: $10.6007 /$ IJARBSS/v9-i1/5865

Received: 26 Nov 2018, Revised: 17 Dec 2019, Accepted: 02 Jan 2019

Published Online: 24 Jan 2019

In-Text Citation: (Mohamed, Mohamad, \& Sarkam, 2019)

To Cite this Article: Mohamed, H. H. A.-B., Mohamad, M. H., \& Sarkam, M. K. A. M. (2019). The Critical Factors towards the Charismatic Leadership Effectiveness in National Defence University of Malaysia. International Journal of Academic Research Business and Social Sciences, 9(1), 1344-1352.

Copyright: (C) 2019 The Author(s)

Published by Human Resource Management Academic Research Society (www.hrmars.com)

This article is published under the Creative Commons Attribution (CC BY 4.0) license. Anyone may reproduce, distribute, translate and create derivative works of this article (for both commercial and non-commercial purposes), subject to full attribution to the original publication and authors. The full terms of this license may be seen

at: http://creativecommons.org/licences/by/4.0/legalcode

Vol. 9, No. 1, 2019, Pg. 1344 - 1352

http://hrmars.com/index.php/pages/detail/IJARBSS

JOURNAL HOMEPAGE

Full Terms \& Conditions of access and use can be found at http://hrmars.com/index.php/pages/detail/publication-ethics 


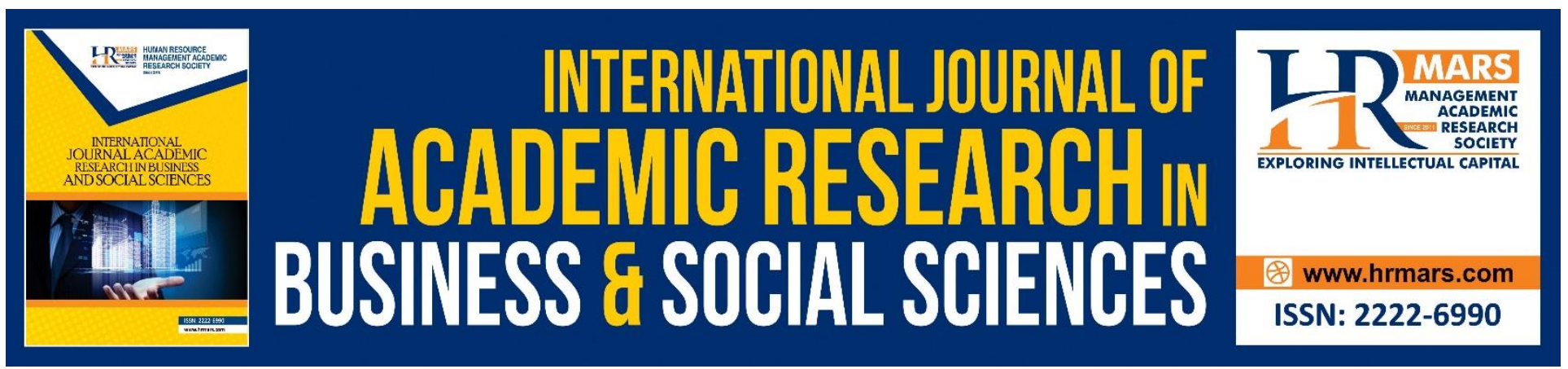

\title{
The Critical Factors towards the Charismatic Leadership Effectiveness in National Defense University of Malaysia
}

\author{
Hj. Hasan Al-Banna Mohamed, Mohd Hamran Mohamad, Mohd \\ Kamarul Amree Mohd Sarkam \\ National Defence University of Malaysia, Malaysia
}

\begin{abstract}
The characteristic of charismatic leadership is very important to be absorbed by the students when they are in university because it can produce quality leaders in the future. The elements of building and understanding for the existence of charismatic leader's attitude are influenced by various factors, either internally or externally. However, the literature review revealed that there is less research focusing on the factors of intellectual and emotion of future leaders, especially among the university students. Therefore, this study focuses on the influence of emotion, spiritual and intellectual factors among students towards the formation of charismatic leader in National Defense University of Malaysia. This study is based on quantitative and qualitative methods that involved respondents who were selected through purposive and random sampling techniques. It was found that all the factors have significant relationships with the effectiveness of charismatic leadership among university students. In conclusion, those factors have given a positive impact in ensuring the sustainability for the formation of effective leaders in the future.
\end{abstract}

Keywords: Charismatic Leadership, Emotional, Spiritual, Intellectual, University Students.

\section{Introduction}

Charismatic leadership is often being a topic of discussion among scholars that benefits the leaders who would bring the success and excellence to an organization. Charismatic leadership style is indeed proved to be an advantage not only to individual subordinate only, but also a positive impact on the entire organization. In this article the researchers focused on the discussion of the relationship or the influence of emotions and intellectual among potential future leaders of the students at the university on charismatic leadership style. This is because lack of such study conducted to explore this area more deeply by looking at what are the impact to the organization and to the students themselves.

In addition, a study on the charismatic leadership is also important because many studies showed that charismatic leadership is described as a style of leadership or ability to easily influence 
INTERNATIONAL JOURNAL OF ACADEMIC RESEARCH IN BUSINESS AND SOCIAL SCIENCES Vol. 9, No. 1, Jan, 2019, E-ISSN: 2222-6990 @ 2019 HRMARS

other groups that are under its authority and finally able to build effective and good governance. According to Waldman et al., the definition of charismatic leadership is a satisfied and comfortable feelings of follower on the leader that are disclosed in the context of leader-follower relationship (Waldman, Ramirez, House, and Puranam, 2001). It can be understood that when a charismatic leader interacts with the followers, the leader confidently explained the targets that should be attained by the followers in order to succeed the organization's vision as determined (Waldman et al., 2001).

Furthermore, based on the views expressed by Bass, (1985), Yukl (2002), Shamir et al. (1993), Conger and Kanungo (1998), the characteristic of charismatic leadership is covering the ability to change the desire of his followers from self-centered to the benefit of all. Besides, it is to enhance the participation and the commitment of the followers towards achieving organizational goals through a continuous motivation provided to them, so that they can contribute something beyond their core responsibility. In addition, according to Bryan, the characteristic owned by the charismatic leader would make his followers glued and encouraged when observing the outstanding behavior displayed by their leaders (Brayan, 2014). In fact, the characteristics of a charismatic leader such as to share a clear vision and mission with his followers, willing to take personal risk, being sensitive to the environment, being able to make changes based on the available resources, responsive to the needs of his followers and the nature of his behavior is unconventional, which tend to transformational leadership style (Brayan, 2014).

Highlighted from the previous studies, it was found that a few studies have focused on factors that determine the effectiveness or causes of charismatic leadership style. Among the factors such as emotions is strongly considered to be the important determinant that affects the individual's success (Goleman, 1995) and style to lead his subordinates. When a leader can understand his emotions, he will be able to manage themselves properly and effectively. Good emotional control reflects the ability of the individual to control from getting angry, sad, frustrated, and so on (Juraimy et al., 2016), especially in leading his subordinates. If the leader's emotions are unstable, often scolding subordinates, feeling stress out and so on, these would do harm to the organisation and the employees.

There are many previous studies by the western and eastern scholars about the influence of spiritual and its relationship with the organizational leadership. The findings consistently prove that the leader's value and practice that is based on strong spiritual aspect is able to influence the subordinate thus, would create a positive attitude, encouraging respectfulness and ethics, instilling mutual understanding among the workers as well as achieving the organizational goal. Spiritual value and practice also lead the individual leader to increase the organization performance, employee's loyalty, promote Barakah and improve work place safety and health. More important, the spiritual practice that mutually performed by the leader and subordinates would lead to the effective organizational leadership (Hicks, 2002).

Besides, the intellectual factor has also become an important element for a leader to lead an activity or organisation. Leaders with high intellectual value; definitely will perform an efficient leadership style, group discussion oriented, openly and behave positively. In fact, according to Schmidt et al., (2009) the intelligence of a chief will be honored by his subordinates and his ideas are able to help the organisation achieves its goals. On the other hand, individuals with low intellectual knowledge in a particular field will give a hard time for the organisation to implement a decision. 
INTERNATIONAL JOURNAL OF ACADEMIC RESEARCH IN BUSINESS AND SOCIAL SCIENCES Vol. 9, No. 1, Jan, 2019, E-ISSN: 2222-6990 @ 2019 HRMARS

Thus, the meaningful intellectual element in promoting charismatic leadership is parallel with the views and the findings of studies carried out by some scholars namely Sternberg $(1985,2011)$, Brody and Brody (1976) and Hunter and Hunter (1984).

Based on the literature review that highlighted the availability of the research gap and the potential study in the area of student leadership, the researchers found that a detailed study should be conducted to explore the relationship between the three factors (emotions, spiritual and intellectual) with charismatic leadership effectiveness among future leaders, particularly the students at a public university in Malaysia.

In consequent to the above discussions, this study focuses on three (3) main objectives:

i. To investigate the relationship between emotional factor with a charismatic leadership among final year students of a National Defence University of Malaysia.

ii. To investigate the relationship between spiritual factor with a charismatic leadership among final year students of a National Defence University of Malaysia.

iii. To investigate the relationship between intellectual factors with a charismatic leadership among final year students of a National Defence University of Malaysia.

Furthermore, based on a literature review discussion, the researchers have developed a conceptual framework of this study, as illustrated in Figure 1.

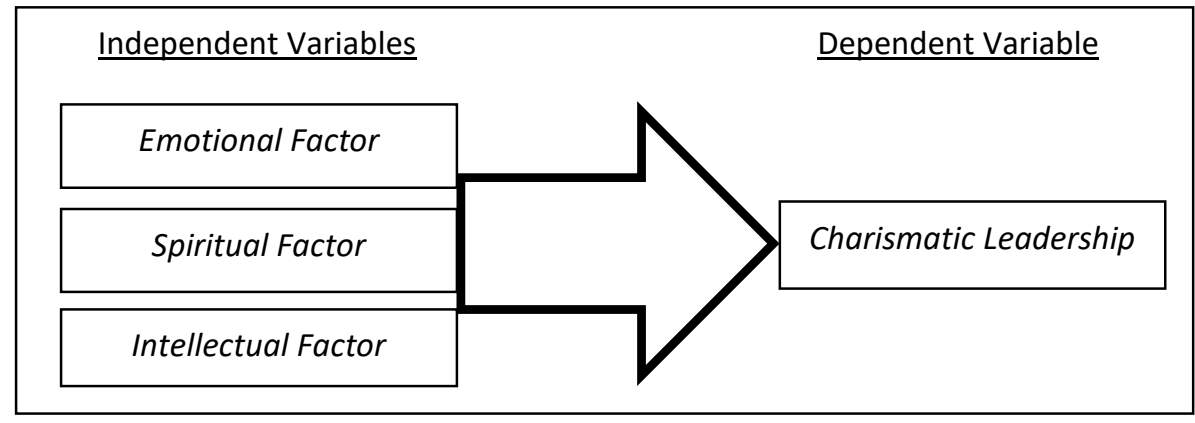

Fig. 1: Conceptual Framework

Based on this conceptual framework, the researchers concluded these three hypotheses to be tested, namely:

Ho1: There is a positive relationship between emotional factor with a charismatic leadership among final year students at a National Defence University of Malaysia.

Ho2: There is a positive relationship between spiritual factor with a charismatic leadership among final year students at a National Defence University of Malaysia.

Ho3: There is a positive relationship between intellectual factor with a charismatic leadership among final year students at a National Defence University of Malaysia.

\section{Methodology}

Research Methods: This study uses two (2) methods; quantitative research which studies the survey, while the qualitative research is through semi-structured interviews. Surveys have used questionnaires distributed to the respondents who were selected by purposive and simple random sampling. Respondents consisted of the final year students of the three (3) faculties at National 
Defence University of Malaysia. The faculties involved were the Faculty of Engineering, Faculty of Science and Technology and Faculty of Management.

Validity and Reliability: To ensure that research is at high level of reliability and reliability, the study should go through the testing process of both aspects. According to Hair et al., (2010) the validity aspect of a study should include three (3) key points i.e., face verification, validity of the content and validity of the construct. The facial confirmation means that items can represent a construct, while the validity of the content covers the texts of an easy-to-understand item and describes the operational purpose of a construct. The last aspect of construct validation is the capability of constructing items to differentiate the convention with other constructs.

Furthermore, the reliability aspect of a study refers to internal consistency where the respondent's acceptance of the items representing a construction is equally and concordant (Sekaran and Baugie, 2016). The pilot study was conducted on 30 respondents and the Alpha Cronbach's value showed an average of 0.67 of each instrument. This proved that the items could be applied to the actual study due to its value that exceeded the value of Alpha Cronbach 0.60. According to Sekaran and Bougie, a value of 0.60 or above indicated that the items have a good level of internal consistency and they are acceptable in measuring the instrument (2016).

Data Analysis: Next, the actual survey forms were modified and sent to 372 respondents with 342 complete responses. This amount reached to the percentage of $92 \%$, and it met the requirement for further analysis as suggested by Zikmund and Babin (2013). In this study, researchers began by performing data scanning using certain tests such as Normality Test, Linearity, and Outliers. Then, the data was analyzed using the factor analysis method for the purpose of determining the validity of the constructs in which the items identified from the previous studies actually represented in the context of this study (Sekaran and Bougie, 2016; Zainudin, 2012). Next, the data were tested using SPSS and AMOS software to identify the differences between control variables in influencing the relationship between independent variables and dependent variables [18]. In addition, the technique of the Equation Model Structure was used for the purpose of testing the relationship between the variables in the study model (Hair et al., 2010; Zainudin, 2012).

\section{Results}

Analysis of demographic profile shows $71 \%$ of respondents are male and $29 \%$ are female. The most is $38 \%$ respondents from Faculty of Science and Defence Technology. It is found $75 \%$ are respondents who have CGPA between 2.70 - 4.00. Whereas, 25\% are respondents who have CGPA below than 2.70 .

Confirmatory factor analysis (CFA) is conducted by AMOS to reveal the validity of constructs used in this study. It is determined based on the factor loading for each item when the CFA model indicates the model fit. The construct validities have been found when there are most of the items have factor loading more than 0.50 as shown in the Figure 2 below. 


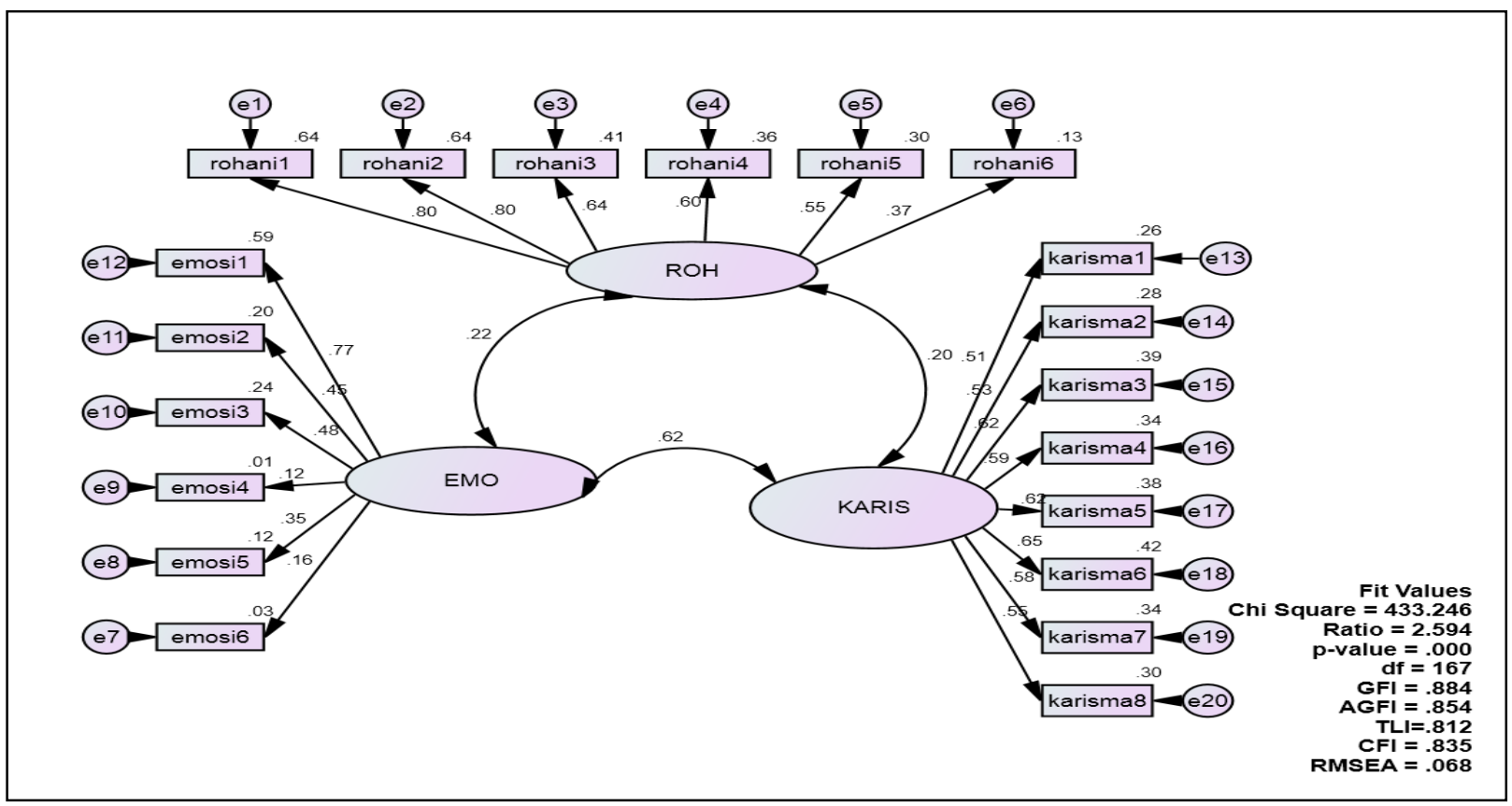

Figure 2: CFA Model

Model fit is performed by deleting two (2) items in spiritual construct, four (4) items of emotion and three (3) items in charismatic leadership. The deleted items are basically having high value of errors which are found in the modification indices table of AMOS output. The model fit indicators can be seen through the SEM model (Figure 3) that indicates RMSEA 0.031 which is less than 0.080 and the GFI, AGFI, TLI and CFI values are more than 0.90 (Hair et al., 2010).

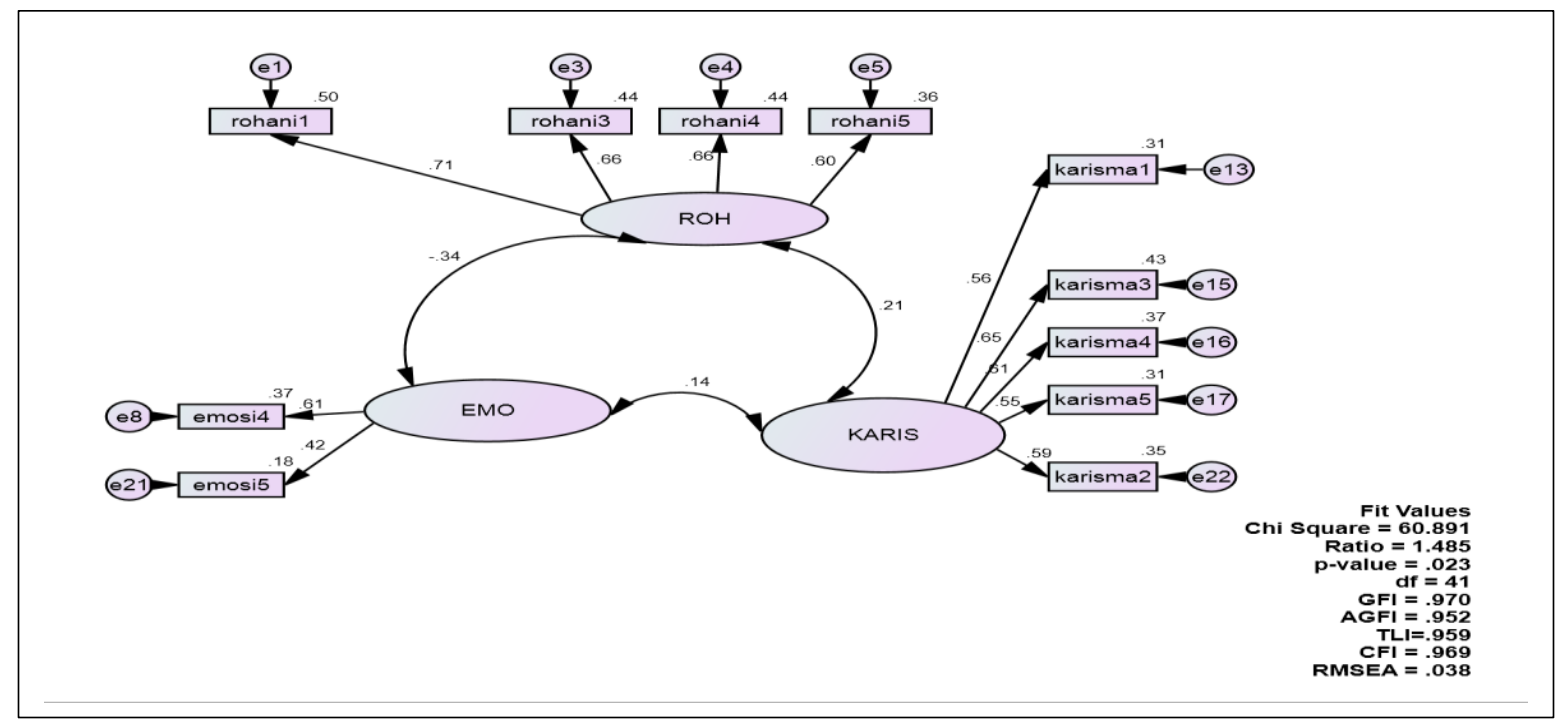

Figure 3: Final CFA Model 
INTERNATIONAL JOURNAL OF ACADEMIC RESEARCH IN BUSINESS AND SOCIAL SCIENCES Vol. 9, No. 1, Jan, 2019, E-ISSN: 2222-6990 @ 2019 HRMARS

The quantitative study was analysed by using SEM AMOS and supported by SPSS software in order to get the result on the relationship between intellectual and charismatic leadership. Whereas, qualitative research through semi-structured interviews was held with a number of selected respondents to support the findings through a feedback questionnaire.

Through a qualitative study using theme development methods and categorised manually, the researchers found that indeed, the three factors were shown to affect the effectiveness of charismatic leadership among students at the university. This implies that all the hypotheses were supported. In addition, reinforces support on the first hypothesis, the study through SEM AMOS technique showed that the effect of emotional and spiritual variables on charismatic leadership are positive and significant by having a Beta value of 0.23 and 0.29 respectively as shown in Figure 4 .

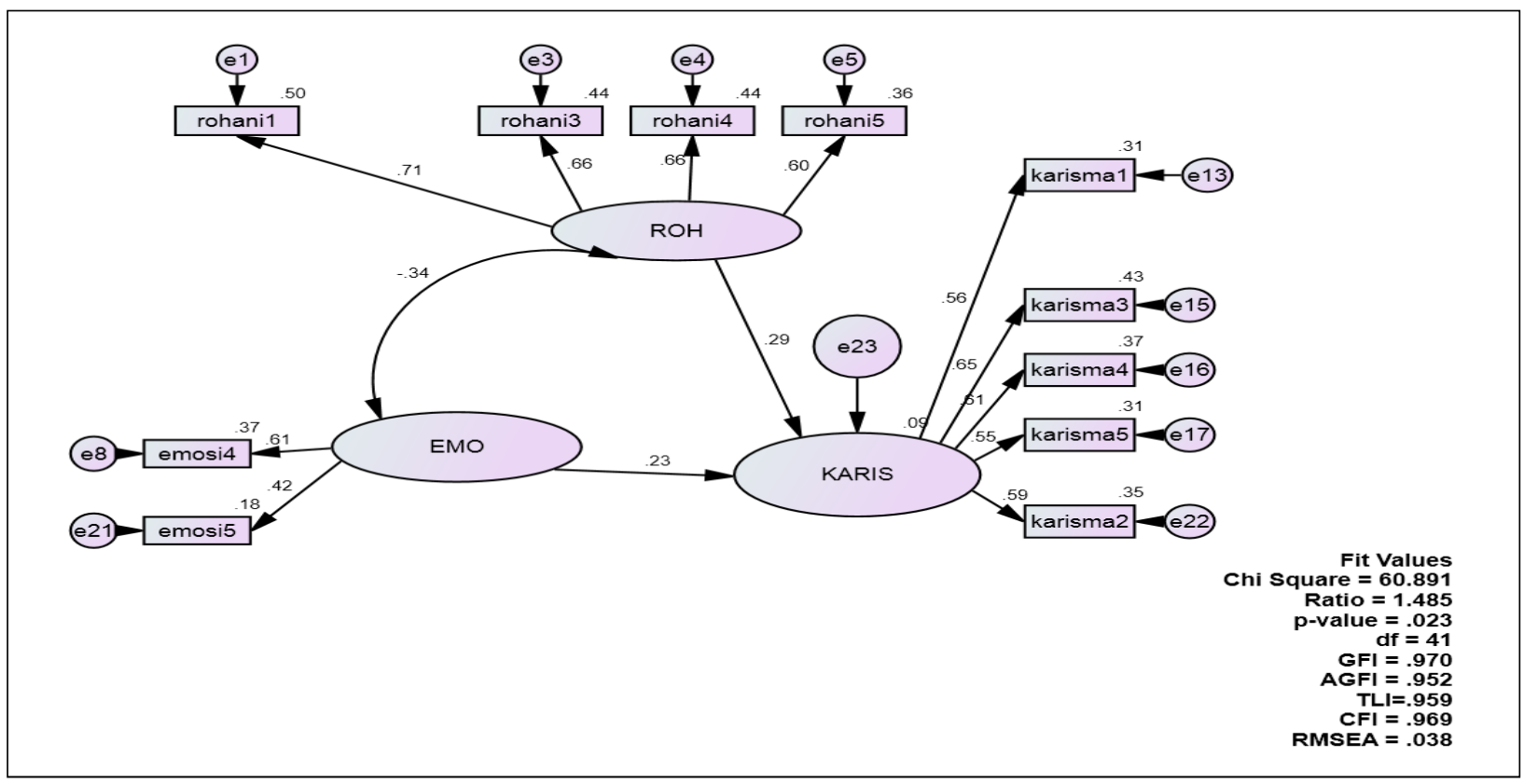

Figure 4: Hypothesis Structuring Model

\section{Discussion}

Through the study, the researchers have mentioned that the first objective of this study is to investigate the relationship between emotional factor with a charismatic leadership. It indicated that the influence of emotions could have a significant impact on the formation of charismatic leadership among the students. It is clear that students in the studied public universities are already having a good level of emotional intelligence (EI) which is the essential internal basis for shaping them towards the charismatic leadership. This finding supports the studies conducted by Shah and Shah, (2004) and Hudani et al., (2013) which stated that emotional intelligence has been confirmed as one of the factors of human resources that can affect the performance of the employees and as a form of measurement of excellence and effectiveness of employees in building their careers (Hudani, et al., 
2013). This includes a person's role as a leader in his career. Thus, the emotional factor is a decisive element for the effectiveness of charismatic leadership style among the students surveyed.

The second objective has been met when spiritual factor positively and significantly affects charismatic leadership. Thus, this result can be interpreted that the cadet officers aware and understand on the needs to increase spiritual and belief values among them This is because this factor is the important principle for them to equip themselves to become good and charismatic leaders. Moreover, the cadet officers will have high motivation to disclose charismatic leadership when they believe on the accurate prosedures and policies of spiritual development initiated by the UPNM management. Their willingness and continuous practice of spiritual improvement become the catalyst of charismatic leadership formation among them. The findings of this study are similar to support the previous studies' findings [9], although those studies were conducted in different context and setting.

The third objective of this study is to investigate the relationship between intellectual factor with a charismatic leadership among respondents. The results found that the effect of intellectual indeed has a direct impact on the development of a charismatic leader. The findings also showed that the majority of respondents have a high level of academic achievement and thus affect their potential to become a leader in the future. It is proven that the result is equal to the findings of the studies that have been conducted by some scholars namely Sternberg (1985, 2011), Brody and Brody (1976), Hunter and Hunter (1984) and Schmidt et al. (2009). In conclusion, this finding clearly showed that the intellectual factor has a positive effect on charismatic leadership style in an organization.

\section{Conclusion}

On completion, the results of this study illustrated that students' emotional level at the studied Public University is already at the intelligent level which is an important factor in the formation of charismatic leadership. In addition, the study revealed that the spiritual and intellectual aspects are also important in building charismatic leadership. Therefore, the institution management should give serious attention to those factors, particularly in developing curriculum and training so that it is able to produce students who are characterised as 'Leaders of Character' (LofC). It is basically, the individual who has the charismatic element as desired by the university management. In addition, this study also sought to support the findings of previous studies and it is hoped that further studies can be continued in a different context and apply the larger research model through the use of new independent variables which has the potential to the formation of charismatic leadership.

\section{Acknowledgement}

This research was supported by Non-Science \& Technology Short Grant from RMC, NDUM. We also thank our colleagues from Faculty of Management and Defence Studies, NDUM who provided insight and expertise that greatly assisted for this study.

\section{Corresponding Author}

Hj. Hasan Al-Banna Mohamed, National Defence University of Malaysia (NDUM), Malaysia, hasanalbanna@upnm.edu.my, Faculty of Management and Defence Studies, NDUM, Sungai Besi Camp, 57000 Kuala Lumpur. 
INTERNATIONAL JOURNAL OF ACADEMIC RESEARCH IN BUSINESS AND SOCIAL SCIENCES

Vol. 9, No. 1, Jan, 2019, E-ISSN: 2222-6990 ㄷ 2019 HRMARS

\section{References}

Bass, B. M. (1985). Leadership and performance beyond expectations. New York: Free Press New York.

Brody, E. B., \& Brody, N. (1976). Intelligence: Nature, determinants and consequences. New York: Academic Press.

Bryan, J. T. (2014). Pengaruh gaya kepimpinan dan motivasi terhadap kinerja karyawan pada PT. Bank Negara Indonesia, TBK (Regional Sales Manado). Jurnal Acta Diurna, 3(4), 1-20.

Conger, J. A., \& Kanungo, R. N. (1998). (Eds.). Charismatic leadership in organizations. Thousand Oaks, CA: SAGE.

Goleman, D. (1995). Emotional intelligent: Why it can matter more than IQ. New York: Bantam Books.

Hair, J. F., Black, W. C., \& Babin, J. B. (2010). Multivariate data analysis: A global perspective. $7^{\text {th }}$ ed. New Jersey: Pearson Education.

Hicks, D. A. (2002). Spiritual and religious diversity in the workplace: Implications for leadership. The Leadership Quarterly, 13(4), August, 379-396. DOI: 10.1016/S1048-9843(02)00124-8.

Hunter, J. E., \& Hunter, R. F. (1984). Validity and utility of alternative predictors of job performance. Psychological Bulletin, 96(1), 72-98. DOI: 10.1037/0033-2909.96.1.72.

Schmidt, D. A., Baran, E., Thompson, A. D., Koehler, M. J., \& Shin, T. S. (2009). Technological pedagogical content knowledge (TPACK): The development and validation of an assessment instrument for preservice teachers. Journal of Research on Technology in Education, 42(2), 123149. DOI: $10.1080 / 15391523.2009 .10782544$.

Sekaran, U., \& Bougie, R. (2016). Research methods for business: A skill-building approach. $7^{\text {th }}$ ed. West Sussex, UK: John Wiley \& Sons Ltd.

Shamir, B., House, R. J., \& Arthur, M. B. (1993). The motivational effects of charismatic leadership: A self-concept based theory. Organizational Science, 4(4), 513-668. DOI: 10.1287/orsc.4.4.577.

Sternberg, R. J. (1985). Beyond IQ: A triarchic theory of human intelligence. New York: Cambridge University Press.

Sternberg, R. J. (2011). The theory of successful intelligence. In Cambridge Handbook of Intelligence, R. J. Sternberg and S. B. Kaufman, (Eds.). New York: Cambridge University Press, 504-527.

Waldman, D. A., Ramirez, G. G., House, R. J., \& Puranam, P. (2001). Does leadership matter? CEO leadership attributes and profitability under conditions of perceived environmental uncertainty. Academy of Management Journal, 44(1), 134-143. DOI: 10.2307/3069341.

Yukl, G. (2002). Leadership in Organization. $5^{\text {th }}$ ed. New Jersey: Prentice Hall. Englewood Cliffs.

Zainudin, A. (2012). Structural equation modeling using AMOS graphic. Shah Alam: University Publication Centre (UPENA), Universiti Teknologi MARA.

Zikmund, W. G., \& Babin, B. J. (2013). Business research methods. $9^{\text {th }}$ ed. South-Western: Cengage Learning. 